\title{
Herpes simplex serious neurological disease in young children: incidence and long-term outcome
}

\author{
Katherine N Ward, ${ }^{1}$ Anu Ohrling, ${ }^{2}$ Naomi J Bryant, ${ }^{1}$ Jennifer S Bowley, ${ }^{1}$ Euan M Ross, ${ }^{3}$ \\ Christopher M Verity ${ }^{4}$
}

'Division of Infection and Immunity, Centre for Virology (UCL Campus), Windeyer Institute of Medical Sciences, University College Medical School, London, UK ${ }^{2}$ Health Protection Agency, Centre for Infections, London, UK

${ }^{3}$ Child Studies Department, King's College, London, UK ${ }^{4}$ Child Development Centre, Addenbrooke's Hospital, Cambridge, UK

\section{Correspondence to} Dr Katherine N Ward, Division of Infection and Immunity, Centre for Virology (UCL Campus), Windeyer Institute of Medical Sciences, University College Medical School, 46 Cleveland Street, London W1T 4JF, UK; k.n.ward@ucl.ac.uk

Accepted 18 May 2011 Published Online First 17 June 2011

\begin{abstract}
Objective To determine the contribution of herpes simplex virus (HSV) to serious neurological disease.

Setting and patients A 3-year prospective survey of children aged 2-23 months in Britain and Ireland.

Results 19 children had HSV central nervous system (CNS) infection; 13 aged 2-11 months had focal neuroimaging abnormalities and 11 long-term neurological sequelae. Of six aged 12-35 months, one had abnormal neuroimaging and three longterm neurological sequelae. 17 of the 19 had serious neurological disease. HSV CNS infection accounted for $23 \%$ of serious neurological disease in children aged 2-11 months and $4.5 \%$ in older children.

Conclusions The incidence of HSV-induced serious neurological disease in the UK was estimated at 1 in 64 000/year in younger children and 1 in 230000 in older children. HSV CNS infection has clinical effects ranging from frank encephalitis to severe illness with fever and convulsions to milder disease lacking encephalopathy.
\end{abstract}

\section{INTRODUCTION}

Herpes simplex encephalitis (HSE) is the most common cause of sporadic encephalitis and without treatment $70 \%$ of patients die. Our knowledge of HSE relies on two clinical trials of antiviral drugs from the 1980s. Since then substantial changes in diagnostic methods, including PCR to test cerebrospinal fluid (CSF) for herpes simplex virus (HSV) DNA together with the use of aciclovir, have improved survival. However, the spectrum of clinical manifestations and longterm outcome need to be better defined so as to improve management and thereby decrease the still considerable morbidity and mortality associated with this devastating condition.

A prospective survey of children aged 2-23 months in Britain and Ireland with serious neurological disease showed for the first time that human herpesvirus- 6 and -7 contributed significantly to this illness. ${ }^{1}$ Data collected included information on other pathogens, including HSV, and thus its contribution to the burden of disease could be assessed. The present paper reports the results obtained.

\section{METHODS \\ Patients}

\section{Case ascertainment}

Between October 1998 and September 2001 paediatricians were requested by the British Paediatric
Surveillance Unit to report the cases of all children 2-35 months old with serious neurological disease. ${ }^{1}$ Neonates were excluded from the survey to avoid inclusion of inherited and mechanical neurological damage which often presents before 2 months of age. Details of each child's neurological illness were collected using a short standard questionnaire. A further brief questionnaire was sent after at least a year to check long-term outcome, that is, whether the child had recovered or suffered developmental delay, persisting neurological deficit or convulsions. An additional questionnaire was sent to the referring hospital's microbiology laboratory to confirm the microbiological results at the time of the child's illness. Each questionnaire was scrutinised by a physician (KNW) to determine whether the details fitted the case definition (see below). Difficult cases were referred to one or more paediatricians (AO, CMV, EMR) for a final decision. The database of all reported disease episodes, regardless of whether or not they met the case definition, was re-examined by KNW for individuals with HSV central nervous system (CNS) infection.

\section{Definitions}

Fever

Fever was defined as a temperature $\geq 37.5^{\circ} \mathrm{C}$.

\section{Serious neurological disease}

1. Severe illness with fever and convulsions

i. with a total duration of $>30 \mathrm{~min}$

ii. followed by encephalopathy for 2-23 h

iii. followed by paralysis or other neurological signs not previously present for $\geq 24 \mathrm{~h}$.

2. Encephalitis

i. Encephalopathy for $\geq 24 \mathrm{~h}$ and two or more of the following:
a. fever
b. convulsions
c. focal neurological findings $(\geq 24 \mathrm{~h})$
d. pleocytosis ( $>5$ leucocytes $/ \mu$ l CSF)
e. characteristic abnormal CT or MRI results.

3. Exclude

i. viral (aseptic) meningitis without encephalopathy

ii. the following confirmed causes: hypoxic/ ischaemic, vascular, toxic, metabolic, neoplastic, traumatic and pyogenic infections

iii. uncomplicated convulsions or a series of convulsions lasting $<30 \mathrm{~min}$

iv. immunocompromised children. 


\section{HSV CNS infection}

1. HSV DNA detected in CSF or an HSV-specific intrathecal antibody response, or

2. Evidence of primary HSV infection, that is, seroconversion to IgG or IgM, within 2 weeks of onset of serious neurological disease.

\section{Ethics approval}

Ethics approval was given by the Public Health Laboratory Service Ethics Committee, London.

\section{RESULTS}

\section{Cases of serious neurological disease}

Of the 267 episodes of disease reported, 19 cases of HSV CNS infection (table 1) and 163 cases of serious neurological disease were identified; 52 of the latter were in children aged 2-11 months and 111 in children aged 12-35 months.

The clinical features, neuroimaging results and long-term outcome of the 19 cases are given in table 2. Every case presented with convulsions (partial in 12/19) accompanied by fever in all but one instance. Focal neuroimaging abnormalities were noted in all children aged $<11$ months (temporal lobes in nine, frontal lobes in three and parietal lobes in seven) but in only one of the older children. There were no deaths, but 11 of the 13 children aged $2-11$ months and three of the six older children had long-term neurological sequelae. The most common sequela was developmental delay, but other persisting deficits included hemiparesis, quadriparesis and visual problems. Eight children had epilepsy.

Two patients (nos. 12 and 15) with HSV CNS infection did not meet our case definition of serious neurological disease.
The remaining 17 (11 encephalitis, six severe illness with fever and convulsions) accounted for $23 \%(12 / 52)$ of episodes of serious neurological disease in children $<1$ year old and $4.5 \%(5 / 111)$ in the older children. Because all 17 cases were in British children, we could estimate the incidence of serious neurological disease due to HSV CNS infection in the UK as 1 in 64 000/year in children aged 2-11 months and 1 in 230 000/ year in children aged 12-35 months. In 1998-2001 there were 2.1 million children in the first year of life and 4.1 million in the second and third years (National Statistics Office website: http://www.statistics.gov.uk/popest).

\section{DISCUSSION}

This paper reports data on the incidence, spectrum of clinical presentation and long-term outcome of virologically confirmed HSV CNS infection in young children throughout the British Isles. So that milder cases would be included, the definition of HSV CNS infection covered more than just serious neurological disease, which in turn comprised not only encephalitis but also severe illness with fever and convulsions.

Thus only $58 \%$ of the children with HSV CNS infection in the survey had an illness that fitted our strict definition of encephalitis as the remainder did not fulfil the criterion of encephalopathy for $\geq 24 \mathrm{~h}$. Such atypical forms of HSV CNS infection have been previously reported ${ }^{2} 3$ and together with our findings show that HSV is responsible for more than clearcut encephalitis in young children.

Cases may have been missed in our survey because HSV DNA or pleocytosis may not be found in CSF soon after disease onset. Likewise, aciclovir treatment may result in the absence of CSF HSV DNA and delay antibody seroconversion.

Table 1 HSV CNS infection: results of laboratory investigations

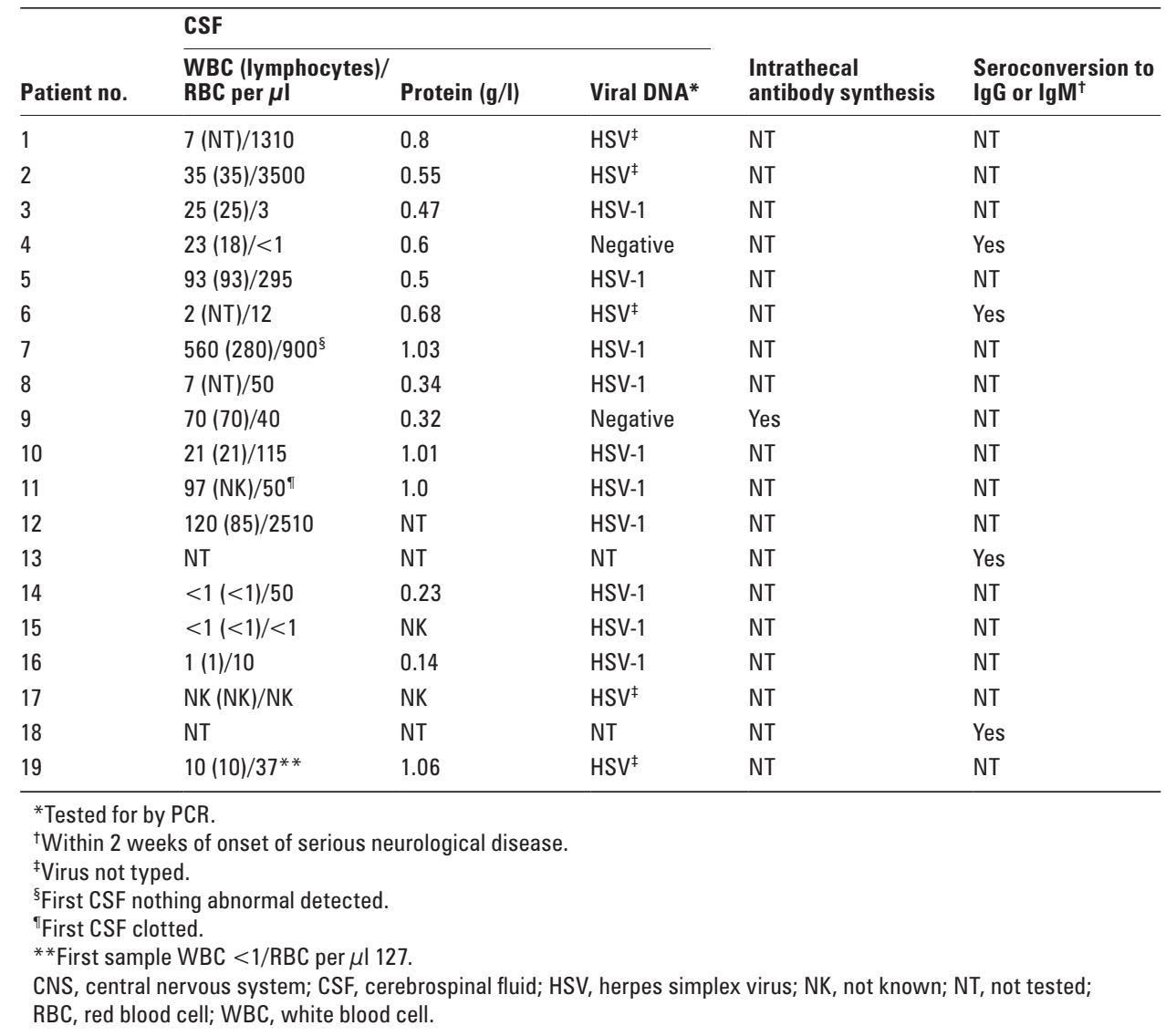


Table 2 HSV CNS infection: clinical features, neuroimaging and long-term outcome

\begin{tabular}{|c|c|c|c|c|c|c|}
\hline Patient (n/sex/age) & Fever $\left({ }^{\circ} \mathrm{C}\right)$ & Encephalopathy & Convulsions (duration) & Lesions on CT & Lesions on MRI & Outcome (time after discharge*) \\
\hline 1/F/3 months & Yes (39.2) & $2-23 \mathrm{~h}$ & Whole body (>30 min) & $\begin{array}{l}\text { Haemorrhagic } \mathrm{R} \text { and } \mathrm{L} \\
\text { hemispheres, oedema }\end{array}$ & ND & $\begin{array}{l}\text { Developmental delay (cognitive } \\
\text { and motor), spastic quadriplegia, } \\
\text { blind, whole body convulsions } \\
\text { (2 years) }\end{array}$ \\
\hline 2/F/4 months & $\mathrm{Yes}^{\dagger}(\mathrm{NK})$ & $\geq 24 \mathrm{~h}$ & $\begin{array}{l}\text { Partial, L hemiclonic } \\
\text { (>30 min) }\end{array}$ & $\begin{array}{l}\text { Haemorrhagic } \mathrm{R} \text { and } \mathrm{L} \\
\text { temporal and parietal }\end{array}$ & ND & $\begin{array}{l}\text { Developmental delay (cognitive), } \\
\text { behavioural problems (4 years) }\end{array}$ \\
\hline 3/M/5 months & Yes (38.2) & $\geq 24 \mathrm{~h}$ & Partial (<15 min) & $\begin{array}{l}\text { Haemorrhagic } R \text { and } L \\
\text { parietal, low density } R \\
\text { and } L \text { temporal and } R \\
\text { parieto-occipital }\end{array}$ & ND & $\begin{array}{l}\text { Developmental delay (cognitive } \\
\text { and motor), hypotonia, L homony- } \\
\text { mous hemianopia ( } 10 \text { months) }\end{array}$ \\
\hline 4/M/6 months & Yes (38.2) & $\geq 24 \mathrm{~h}$ & $\begin{array}{l}\text { Partial (>30 } \mathrm{min} \text { ) and } \\
\text { L hemiplegia } \geq 24 \mathrm{~h}\end{array}$ & Low density bifrontal & ND & $\begin{array}{l}\text { Developmental delay (cognitive } \\
\text { and motor), L hemiplegia, whole } \\
\text { body convulsions ( } 3 \text { years) }\end{array}$ \\
\hline 5/M/6 months & Yes (38) & $\geq 24 \mathrm{~h}$ & $\begin{array}{l}\text { Partial L-sided } \\
\text { (>30 min) and L } \\
\text { hemiplegia } \geq 24 \mathrm{~h}\end{array}$ & $\begin{array}{l}\text { Haemorrhagic, low den- } \\
\text { sity } L \text { frontal, temporal } \\
\text { and parietal }\end{array}$ & $\begin{array}{l}\mathrm{R} \text { cerebral } \\
\text { hemisphere }\end{array}$ & $\begin{array}{l}\text { Developmental delay (cognitive } \\
\text { and motor), } L \text { hemiplegia and con- } \\
\text { vulsions ( } 2 \text { years) }\end{array}$ \\
\hline 8/M/8 months & Yes (38.5) & $\geq 24 \mathrm{~h}$ & $\begin{array}{l}\text { Partial, R-sided } \\
\text { with oculogyric crisis } \\
\text { (>30 min) }\end{array}$ & $\begin{array}{l}\text { Low density temporal } \\
\text { lobe }\end{array}$ & ND & Recovered (1 year) \\
\hline 9/F/10 months & Yes (NK) & $\geq 24 \mathrm{~h}$ & $\begin{array}{l}\text { Whole body } \\
\text { (15-30 min) }\end{array}$ & $\begin{array}{l}\text { Low density } \mathrm{R} \text { temporal } \\
\text { and parietal }\end{array}$ & $\begin{array}{l}\mathrm{R} \text { temporal } \\
\text { - no normal } \\
\text { parenchyma }\end{array}$ & $\begin{array}{l}\text { Developmental delay (cognitive } \\
\text { and motor), autism, convulsions } \\
\text { (4 years) }\end{array}$ \\
\hline 10/F/10 months & Yes (38.5) & $\geq 24 \mathrm{~h}$ & Whole body (<15 min) & $\begin{array}{l}\text { Low density } R \text { and } \\
L \text { temporal lobe, ser- } \\
\text { piginous enhancement } \\
R \text { sylvian fissure }\end{array}$ & ND & $\begin{array}{l}\text { Developmental delay (cognitive) } \\
\text { (1 year) }\end{array}$ \\
\hline 14/F/14 months & Yes (37.8) & $\geq 24 \mathrm{~h}$ & $\begin{array}{l}\text { Partial, clonic R arm } \\
\text { (15-30 min) }\end{array}$ & Normal & ND & Recovered (NK) \\
\hline 15/F/17 months & No & $\mathrm{NK}^{\S}$ & Whole body (>30 min) & Normal & ND & $\begin{array}{l}\text { Convulsions, absences but attends } \\
\text { normal school ( } 2.5 \text { years) }\end{array}$ \\
\hline 16/F/17 months & Yes (39.2) & $<2 \mathrm{~h}$ & Whole body (>30 min) & Normal & ND & Recovered (1 year) \\
\hline 17/F/18 months & Yes (39.0) & $2-23 \mathrm{~h}$ & $\begin{array}{l}\text { Whole body ( }<15 \mathrm{~min}) \\
\text { and ataxia } \geq 24 \mathrm{~h}\end{array}$ & Normal & $\begin{array}{l}\text { Diffuse high signal } \\
\text { in white matter } \\
\text { around ventricles }\end{array}$ & Hemiparesis (2.5 years) \\
\hline 18/M/26 months & Yes (37.5) & $\geq 24 \mathrm{~h}$ & $\begin{array}{l}\text { Partial ( }>30 \mathrm{~min}) \\
\text { ataxia } \geq 24 \mathrm{~h}\end{array}$ & Normal & ND & $\begin{array}{l}\text { Developmental delay (motor and } \\
\text { cognitive) ( } 4 \text { years) }\end{array}$ \\
\hline 19/M/35 months & Yes (38.5) & $2-23 \mathrm{~h}$ & $\begin{array}{l}\text { Partial and whole body } \\
(15-30 \mathrm{~min}) \text { and ataxia } \\
\geq 24 \mathrm{~h}\end{array}$ & Normal & Normal & Recovered ( 3.5 years) \\
\hline
\end{tabular}

*Depended on date child last seen and date of return of the questionnaire.

${ }^{\dagger}$ Preceding admission.

${ }^{\ddagger}$ Hemiplegia for $<24 \mathrm{~h}$.

${ }^{\S}$ Ictal, given thiopentone and transferred to paediatric intensive care unit at another hospital. Patient described as encephalopathic but duration not given - not possible to differentiate drug-induced from virus-induced encephalopathy.

CNS, central nervous system; HSV, herpes simplex virus; ND, not done; NK, not known.

Indeed, nowadays CSF is rarely tested for intrathecal HSV antibody ${ }^{4}$ and this was certainly our experience. Finally, the declining use of HSV serum antibody tests together with a decrease in the use of lumbar puncture in paediatric practice may have affected detection. ${ }^{5}$ However, it seems that in fact few cases were missed. Analysis of Hospital Episode Statistics
(HES) for England over 1998-2001 gives 52 cases of HSE in children $<3$ years old (data not shown). This figure is necessarily higher than ours since it includes neonates in whom HSE occurs in appreciable numbers (76 cases in 1986-1991, 83 cases in 2004-2006). ${ }^{6}$ Thus, although the HES data lack confirmatory virological evidence and a uniform case definition, they 
fit well with our finding of postnatal HSV CNS infection if allowance is made for exclusion of neonates.

HSE classically presents as an acute illness characterised by fever and encephalopathy together with behavioural disturbances and/or motor deficits and/or convulsions. No sign is pathognomic, but it is noteworthy that in our children $<3$ years old, convulsions (generalised or focal) were present in every case. Similarly, two studies of postnatal $\mathrm{HSE}^{27}$ report a predominance of convulsions in children aged $<3$ years as compared to older children who show a wider range of presentations.

Neuroradiology of postnatal HSE typically reveals focal haemorrhagic lesions localised to the medial temporal lobes, the insula and the orbital region of the frontal lobes of the brain. However, in our series the parietal lobes were frequently affected, confirming previous findings that in young children extra-temporal regions of the brain are often involved. ${ }^{2} 38$

HSE outcome is difficult to predict early on and particularly in very young children in whom subtle defects may appear later; it is therefore important that almost all of our cases were followed up at least a year after presentation. Long-term sequelae were reported in many of the children. Adverse outcome was age-related and CT reflected this as abnormalities were described in all the younger children but in none aged $>11$ months. Likewise, high numbers of red cells in the CSF, reflecting haemorrhagic necrosis in the CNS, were confined to the younger age group. Of other recent studies of the long-term outcome of HSV CNS infection, that is, at least 6 months after onset, $^{2910}$ one $^{10}$ reported that patients 3-35 months old were more likely to be severely disabled than older children. Our series further suggests that those $<1$ year old were at highest risk. Poor neurological outcome is associated with delayed initiation of aciclovir therapy and/or shorter courses of the drug but, although all children received aciclovir, the confounding effects of inadequate treatment could not be addressed as this information was not collected by us nor in the study of Ito et al. ${ }^{10}$ The influence of age of onset in relation to severity of long-term outcome requires prospective study taking into account the role of inadequate aciclovir therapy.

In conclusion, this survey documents the incidence of HSV-induced serious neurological disease in young children in Britain and emphasises that there are various presentations ranging from frank encephalitis to severe illness with fever and convulsions, and even a milder form lacking lengthy encephalopathy. Disease was commoner in children aged 2-11 months than in older children, and neurological sequelae and consequent severe disabilities showed the same trend. HSV CNS infection must always be considered in children presenting with convulsions even when apyrexial, without encephalopathy and with normal CT findings.

Acknowledgements The authors thank the British Paediatric Surveillance Unit, supported by the Department of Health, for facilitating the data collection and the reporting clinicians, particularly those who completed the questionnaires. Any views expressed (in publications) are those of the investigator and not necessarily those of the BPSU or DH. The authors are also grateful to the microbiologists and virologists who took the time and trouble to send specimens in support of the survey.

Funding The authors thank the Wellcome Trust for funding (project grant $051350 / Z$ to KNW). Analysis of HSV CNS infection was made possible by funds from the Encephalitis Society's 10th Anniversary Research Prize to KNW. KNW was supported in part by funding from University College London/University College London Hospitals Comprehensive Biomedical Research Centre.

Competing interests None.

Ethics approval This study was conducted with the approval of the Public Health Laboratory Service Ethics Committee, London, UK.

Provenance and peer review Not commissioned; externally peer reviewed.

\section{REFERENCES}

1. Ward KN, Andrews NJ, Verity CM, et al. Human herpesviruses- 6 and -7 each cause significant neurological morbidity in Britain and Ireland. Arch Dis Child 2005;90:619-23.

2. Elbers JM, Bitnun A, Richardson SE, et al. A 12-year prospective study of childhood herpes simplex encephalitis: is there a broader spectrum of disease? Pediatrics 2007;119:e399-407.

3. De Tiège $\mathbf{X}$, Rozenberg $F$, Héron $B$. The spectrum of herpes simplex encephalitis in children. Eur J Paediatr Neurol 2008;12:72-81.

4. Chataway J, Davies NW, Farmer S, et al. Herpes simplex encephalitis: an audit of the use of laboratory diagnostic tests. OJM 2004;97:325-30.

5. Kneen R, Solomon T, Appleton R. The role of lumbar puncture in children with suspected central nervous system infection. BMC Pediatr 2002;2:8.

6. British Paediatric Surveillance Unit. 21st Annual Report 2006-2007. 2006:P43-5 http://bpsu.inopsu.com/publications/annual_reports/BPSU_Annual_report_2006-7. pdf (accessed 17 July 2010).

7. De Tiège $\mathbf{X}$, Héron $B$, Lebon $P$, et al. Limits of early diagnosis of herpes simplex encephalitis in children: a retrospective study of 38 cases. Clin Infect Dis 2003;36:1335-9.

8. Schlesinger Y, Buller RS, Brunstrom JE, et al. Expanded spectrum of herpes simplex encephalitis in childhood. J Pediatr 1995;126:234-41.

9. Lahat $\mathbf{E}$, Barr J, Barkai G, et al. Long term neurological outcome of herpes encephalitis. Arch Dis Child 1999;80:69-71.

10. Ito $\mathbf{Y}$, Ando $\mathrm{Y}$, Kimura $\mathrm{H}$, et al. Polymerase chain reaction-proved herpes simplex encephalitis in children. Pediatr Infect Dis J 1998;17:29-32. 